\title{
Stock market under the 2016 Brazilian presidential impeachment: a test in the semi-strong form of the efficient market hypothesis ${ }^{*}$,*
}

\author{
Alexandre Ricardo de Aragão Batista ${ }^{1}$ \\ (D) https://orcid.org/0000-0002-7236-9056 \\ Email: alexandre.ricardo.batista@usp.br \\ Uxi Maia ${ }^{2}$ \\ (D) https://orcid.org/0000-0002-5324-2869 \\ Email: uximaia@hotmail.com \\ Alécio Romero ${ }^{3}$ \\ (D) https://orcid.org/0000-0003-0647-2079 \\ Email: alecioromero@gmail.com
}

Received on 04.10.2017 - Desk acceptance on 05.19.2017 - $3^{\text {rd }}$ version approved on 12.14.2017 - Ahead of print on 06.18.2018

Associate Editor: Fernanda Finotti Cordeiro Perobelli

\begin{abstract}
This article aims at contributing to study the stock market's reaction up to the point of generating significant abnormal returns or cumulative abnormal returns within the Brazilian impeachment period. By means of the efficient market hypothesis $(\mathrm{EMH})$, in its semi-strong form, the purpose was verifying whether the presidential impeachment that took place in Brazil in 2016, in 3 different dates, brought the expected reaction from the stock market on the Brazilian Stocks, Commodities and Futures Exchange (BM\&FBOVESPA). The theme is relevant, as it addresses aspects of politics and economic theory and their interactions in stock markets. It impacts in the area of capital markets, because this suggests that economic players can, through their expectations and information, see adverse reactions in the market. The methodology analytically employed encompasses a brief literature review as a theoretical basis about the institutions involved and it refers historically to impeachment events. Quantitatively, the methodology consists in the study of events, so that the expectations are observed by means of time-series regression models based on the autoregressive-moving-average (ARMA) models. The result found, under three major events that culminated in the 2016 Brazilian presidential impeachment, was that no significant statistics has been determined, at a 5\% level, in all estimated windows and in all events. Statistically, it was not possible to reject the hypothesis that the abnormal returns and the cumulative abnormal returns equal zero. So, the markets have been considered to be well-informed regarding the events, in this specific situation, i.e. according to the EMH, in its semi-strong form, the markets have reacted as expected.
\end{abstract}

Keywords: study of events, market efficiency, information asymmetry, political economy, impeachment.

Correspondence address

Alexandre Ricardo de Aragão Batista

Universidade Estadual de Campinas, Instituto de Economia

Rua Pitágoras, 353 - CEP: 13083-857

Cidade Universitária - Campinas - SP - Brazil

* Paper presented at the 22 ${ }^{\text {nd }}$ Brazilian Congress of Economics, entitled "Stock Market Pricing and the 2016 Brazilian Presidential Impeachment," Belo Horizonte, MG, Brazil, September 2016.

** The authors thank Ph.D. Professor Liliam Carrete (FEA-USP) and Ph.D. Professors Gerlando Lima (FEA-USP) and Claílton Ataídes (UFSM) for their theoretical and methodological suggestions. 


\section{INTRODUCTION}

This article aims to contribute to study efficiency in the Brazilian stock market in face of a political event. The purpose, by analyzing studies of events, consists in verifying whether the presidential impeachment that took place in Brazil in 2016, in 3 different dates, provided abnormal returns to the stock market on the Brazilian Stocks, Commodities and Futures Exchange (BM\&FBOVESPA), i.e. whether the market reaction to the event under analysis occurred as expected and, consequently, whether the market was efficient.

We take into account that information is a broad concept and it involves, among other things, data and political contexts. Then, in addition to business results, macroeconomic announcements, etc., political stability is also a variable that may be relevant and impact on decisions of economic players. Assuming that the latter, when inserted in the markets, want to maximize their revenues subject to certain restrictions, it is assumed that they also seek abnormal returns, if not for profit, at least to preserve the value of their invested wealth.

By hypothesis, if there is political imbalance as a starting point, this situation may be the genesis of an economic imbalance and, consequently, affect the financial market. In this way, the best informed players are benefited. Given this information privilege assumption, it may involve information asymmetry in which abnormal results may emerge and the markets could not be regarded as efficient.

Such an opportunity could have arisen due to the troubled political situation observed in the country after the 2014 elections. The first issue is that this belief would lead to the common sense that the stock market could have provided abnormal returns, in this particular case. This would derive, for instance, from information asymmetry in which players could have monopolized information about the type of vote that politicians would choose in the 3 phases of voting for the impeachment. However, given the press coverage, it was also assumed that such asymmetry was not that high, on the contrary, it had already created an expectation of pro-impeachment results that allowed the market to adjust to an expected result.
This might bring a second problem, perhaps the rise of a myopia indicating that the Brazilian market could be really efficient.

As previously expressed, this article contributes to debate the market efficiency in situations that are political in nature, such as the impeachment. This extraordinary fact involves expectations of economic players accustomed to certain 'rules of the game.' Although there may seem to have been a sudden change when observed in the country's historical trait, the aggregate perception of those who experienced the moment may have been just waiting for the obvious to happen in a region whose phenomenon is recurrent. This obvious fact can also be explored in studies by other authors, regarding market efficiency issues involving political events, above all in elections, since impeachment trials do not always take place, as section 2.4 presents.

In order to fulfill the work, we resorted to returns from the BOVESPA Index (IBOVESPA) - theoretical portfolio of assets prepared by the BM\&FBOVESPA - as a proxy for the Brazilian stock market and we analyzed whether the 2016 Brazilian presidential impeachment provided abnormal returns on assets. Using the method of study of events, tests were performed in the semi-strong form of the efficient market hypothesis (EMH), in order to verify whether there was any abnormal return (AR) or cumulative abnormal return (retorno anormal acumulado - RAA) due to the impeachment. To calculate the expected normal return, time-series regression models based on autoregressive-moving-average (ARMA) models, i.e. (p, q), provided the expected value.

In addition to this introduction, the article has section 2 , with the literature review, which brings to the debate issues relating politics and market returns, a review of the EMH explanation, studies on Brazil, and approaches provided by some recent papers, contextualized in the issue outlined herein in political terms. Section 3 shows the quantitative methodology used. Section 4 presents the results. And section 5 brings the final remarks.

\section{LITERATURE REVIEW}

It is intuitive to believe that changes in political regimes, government actions, and political turbulence, in general, cause economic impacts. Even considering financial or capital markets belonging to a larger group, i.e. the economy, extra-economic factors may have an impact in order to increase their volatilities or provide decisions beyond expectations. 


\subsection{Changes in Political Contrasts - Rules of the Game}

Economics and politics must be in line so that the rules are clear among players, because moments of crisis in one of these social spheres may bring, as a result, economic reforms or a revolution in the current political system. Rules should be clear so that the market can be as efficient as possible with the least extra-economic intervention.

Institutions play a major role in the process of establishing the rules of the game. North (1990) believes the institutions set the rules of interaction of people in society, i.e. economic, social, and political relations. According to this theoretical perspective, changes are interrelated and individual actions have a rationality limited by the rules in force. Since the economic structures are constituted by institutions, participants try to retain most of the benefits by organizing the latter in ways that bring them advantages.

Acemoglu (2005) corroborates the conception of rules that coordinate social structures, highlighting issues related to the economic performance of a country, given its institutional and political formation. The contrast between politically weak and strong States determines the conditions for maintaining a political and economic stability that encourages the creation and evolution of good institutions, thus promoting greater economic growth, innovation, and greater social benefit. Politically weak countries tend to invest little in infrastructure and have little control over economic activities. At the other extreme, those politically strong overtax economic activities and interfere with the private business relations in a peculiar way, which can undermine the economic performance. The middle way, i.e. proper distribution between the society's power and the State's political power, would be needed for a more efficient functioning of the economy, which can result in political stability and clear rules for players.

To illustrate, an investment policy adopted by a country in both ways presented herein has a nature complementary to the activities of private players, therefore, it provides information to these players on their possible future restrictions. Such information may indicate, among other things, taxes that will be imposed for making the investment strategy practicable. In general, interest rates on the economy, inflation, average income, legislation, political activities, etc. provide information that can, in an economic sense, signal what the rules of the game are for the State (Acemoglu, 2005).

Another relationship between politics and its influence on the economy, and vice versa, is brought to light through the analysis provided by Van der Brug, Van der Eijk and Franklin (2007), in which political and economic relations are exemplified through elections and the way how rulers are subject to economic performance to remain in power. In favorable economic situations, according to the authors, the permanence in power of a particular party or political elite is more likely than under conditions of economic crisis, because, in a democratic system, votes are influenced by the economic performance of the country or region that, in turn, is associated with the rulers' political capacity and ability.

The theme addressed in this subsection does not constitute an exercise of easy abstraction, even in terms of scientific research. It is worth emphasizing that the purpose of this section is only showing the interconnection between politics and economics in terms of information relevance and its impacts on the market, without entering into merits and value judgments concerning such a theme. The economy is, in general terms, the main set in which the markets are inserted, as well as the political relations. Therefore, herein nothing is done besides providing a panorama on economics and politics.

\subsection{Efficient-Market Hypothesis}

In this article, it is understood that the price formation of an asset lies on the EMH, which provides a normal return. In Fama (1970), it is assumed that asset prices reflect all available information. In turn, a market that always fully reflects available information is named as 'efficient.' The author, in his study, determines the division of information into three subsets, and then he tests them. The subsets were classified into:

- Efficient in the weak form, where the information set consists only in historical prices;

- Efficient in the semi-finished form, where prices adjust efficiently after other information becomes publicly available;

- Efficient in the strong form, where asset prices adjust even if investors or groups have a monopoly on information access.

In order to better adjust prices in face of the information set, Fama (1970) sees three sufficient conditions for the efficiency of capital markets:

i. There are no transaction costs on the assets traded;

ii. All available information is available at no cost on the market;

iii. Everyone agrees on the implications of current information on current prices and distribution of future prices of each asset. 
These conditions are hardly met in practice. However, such conditions are sufficient, but not necessary. When carrying out the empirical tests, their results showed that the weak form reached statistical significance. In turn, the semi-strong and strong forms showed consistency with the EMH.

However, as there is information asymmetry and transaction costs in practice, Fama (1991) argued that the EMH was false, but he stressed its importance to be used as a benchmark. Each person would be free to judge the scenario in a market and how close it might be to the hypothesis. In Fama (1991), there is a change in the classification of subsets and their forms for operationalization. In general, the main characteristics did not change significantly. The new classifications are provided in Table 1, just as proposed by Lima, Yamamoto, Lima and Malacrida (2008).

Given the hypothesis that the assets provide normal results in terms of information, political instabilities, they presumably make the market more volatile. More than mere negotiations based on hypotheses with economic and accounting rationale, sometimes the capital market ends up escaping rationality. Returns might also capture periods of indecision, i.e. a psychological aspect of the negotiating mass. Elder (2002) sees that, faced with such a situation, an experienced trader 'stands aside.' 'Standing aside, or not participating in stock exchange negotiations, is also a legitimate market position and this prevents you from losing money.

Table 1

Old classification, characteristic, and new classification

\begin{tabular}{ccc}
\hline Old classification & Characteristic & New classification \\
\hline Weak form & $\begin{array}{c}\text { The market fully incorporates the information } \\
\text { on past bond prices, i.e. abnormal returns } \\
\text { (above the market average) could not be } \\
\text { obtained based on the expectations that past } \\
\text { prices are good signals of future prices. }\end{array}$ & Predictability by past returns \\
Semi-strong form & $\begin{array}{c}\text { Prices reflect not only the history of price } \\
\text { behavior, but also all public information, } \\
\text { such as company balance sheets, } \\
\text { press releases, relevant facts, etc.. }\end{array}$ & Studies of events \\
\hline Strong form & $\begin{array}{c}\text { In addition to the above-mentioned information } \\
\text { (history of prices and public information), } \\
\text { prices reflect non-public (private) information. }\end{array}$ & Private information tests \\
\hline
\end{tabular}

Source: Adapted from Lima et al. (2008).

It is worth noticing, however, that the study of events for the EMH is not aimed only at political issues, but at various circumstances that can be captured. For instance, Lima et al. (2008), through the positive accounting theory and the EMH, have verified whether the information provided to the capital market about the intention to issue American Depositary Receipts (ADRs) among Brazilian companies generates abnormal returns in the stock prices of these companies.

In turn, Camargos and Romero (2006) analyzed efficiency in the Brazilian market by studying the behavior of abnormal returns accumulated within the period following the disclosure of three corporate events - mergers and acquisitions, launching of ADRs, and adherence to distinctive levels of corporate governance. The authors tried to identify whether the market behaved efficiently as in the semi-strong form.

This article presents a study based on the EMH assumption and it uses as an event the voting dates of the presidential impeachment, as explained in section 2.3. The next section explains how the analysis was operationalized.

\subsection{Impeachment - Recurring Case}

The literature in subsection 2.1 has provided sufficient information to infer that regimes can collapse at any time, either being solid or fragile. It is also possible to infer that, in contemporary times, military regimes are not well liked by the societies of advanced countries and the legitimacy of acquired power is hardly put into question if the representative is elected through the socalled democratic means, or ballot boxes. However, if the elected authority is not acting according to a specific social contract - the constitution or other legislation, for instance - it will be subject to sanctions or loss of mandate. Alternatively, if it is not aligned with any elite group or groups - even countries, for instance, the United States of America (USA), or their elites - it may suffer some kind of opposition that, being so strong, may even lead to the fall. 
Brazil, particularly, has a recurring history of deposition of government authorities. Either at the time the Portuguese Empire fell, at the seizure of power by Vargas, or at the establishment of the military dictatorship in 1964. The post-1980 democratic consolidation came along with the election of Fernando Affonso Collor de Mello, in 1989 , totalling more than 35 millions of voters. However, according to Sallum Jr. and Casarões (2011), over time, this president lost popular prestige, his government was hit by allegations of corruption, and he was unable to command the country on a political basis. Accused by his brother, in May 1992, of membership in a corruption scheme with the treasurer in charge of his election campaign, a Brazilian Parliamentary Inquiry Commission (CPI) was formed, which confirmed his involvement. Amid a wave of demonstrations, the Chamber of Deputies authorized the impeachment process to be triggered. The Federal Senate approved it in December the same year and Collor was taken away from the political scene for eight years.

In turn, the extremely disputed 2014 presidential election ended in the second round and it set the country president's victory with about $52 \%$ of the valid votes. During the mandate, however, due to a series of economic and political issues, a scenario of rejection by a population portion and the business sector emerged.

Under a series of allegations mainly against the government allies, ranging from corruption in the company whose stock majority control belongs to the Union, the Petrobras, to involvement with contractors, and the latter led to voting in the Chamber of Deputies was that breaking the Brazilian Fiscal Responsibility Law. On December 2, 2015, the Chamber's speaker accepted the prosecution proceedings. Then, a special commission was formed to analyze them and the bureaucratic procedures that led to the cassation months later.

Chronologically, on April 17, 2016, the Chamber of Deputies plenary session provided 367 votes against 137 in favor of the document suggesting the cassation. On May 12, 2016, the Senate approved the proceedings to be triggered, which suspended the functions of the presidential authority. After three months of processing, the Federal Senate approved the impeachment. On August 31,2016 , Brazil confirmed the second impeachment of an elected president in its history (Brasil, 2016).

\subsection{Recent Efficiency Studies: Some Approaches in the Brazilian and International Markets}

Regarding the international papers addressing politics and the EMH, it is usual to find those dealing with the election season. For instance, among the most recent papers, Gemmil (1992) addressed political risks and market efficiency in the 1987 London elections. In that election, it was widely anticipated that the Conservative Party would win by an approximate $12 \%$ margin on the Labor Party. It was expected that if the Labor Party won, there would be a $10-20 \%$ drop in the market, whereas if Conservative Party won, the market was expected to rise, due to Japanese investment inflows. In his article, the author aimed to test whether stock prices and options during the election were consistent with opinion polling information, i.e. whether there was semi-strong efficiency. For stock prices, a simple model has been developed and it revealed a close relationship between the probability of a conservative party winning and the level at the Financial Times Stock Exchange 100 (FTSE 100) index. For the options, a jump diffusion model was used to reveal whether prices were inconsistent with polls within the last election week.

In his article, it was found that the FTSE 100 index was informationally efficient concerning the surveys. On the other hand, some option prices have proved to be extremely volatile. Although the polls indicated a likely victory for the Conservative Party, the options index said otherwise. The options were informationally inefficient. The author's interpretation was that these option results were due to a race of ill-informed speculators in this market in the last campaign week. However, Gwilym and Buckle (1994) replicated the work for the 1992 elections. In this situation, the results showed that the stock market was semi-strong. In turn, the options market, while not closely following the polls, provided results whose level of inefficiency, this time, was insufficient to allow riskfree arbitrage profits. The authors believed that one of the reasons could be the increased amount of liquidity in trading volumes of the options index.

Still in the election context, Aggarwal and Smith (2015) analyze the possibility of using data from presidential polls to obtain abnormal returns. The survey encompassed election cycles from 1976 to 2012 and price cycles from more than 80 sectors. Their results show that economically significant gains based on Gallup survey data exist three months before the election. Since there is already an idea of who will win the election, positions could be taken in those sectors likely to produce positive returns based on potential winners.

Altin (2015), by means of several authors, reviews the EMH and analyzes its pros and cons. The author verifies that the hypothesis is insufficient to explain anomalies recently experienced, that the latter particularly occur in election periods, and that investors are aware of this. He believes that if the EMH were valid, this anomaly form would not be experienced, so its magnitude varies 
according to the market. In addition, after the elections, expectations of withdrawal occur and a greater anomaly is a reflection of uncertain electoral periods.

In turn, in Brazil, Camargos and Barbosa (2006), by means of studies on merger and acquisition announcements in the BOVESPA, between July 1994 and July 2002, investigated whether the Brazilian capital market after the Real Plan started taking the form of semistrong information efficiency. The authors found that abnormal returns, accumulated within a 20-day window of events, evidenced the absence of a standard behavior for the series as a whole and that, at time $t_{1}$, there was a significant increase in abnormal returns, not in an efficient way. Their empirical evidence showed that the Brazilian capital market did not behave in an informationally efficient manner during the period analyzed, in terms of mergers and acquisitions.

Medeiros and Barbosa (2007) analyzed the behavior of the Brazilian stock market between 2001 and 2005, in order to verify the existence of market efficiency after the occurrence of favorable and unfavorable shocks. To use the methodology of study of events, the return of the IBOVESPA against the Dow Jones Index as a proxy of the world market was regressed. Their results indicate that market efficiency was not found for both positive and negative events.

Forti, Peixoto and Santiago (2009) analyzed the EMH in the Brazilian capital market through documentary and electronic research. They used the bibliographical survey of renowned authors who wrote about the theme and found out that the market is not fully efficient. They noticed that, in the weak form, $42 \%$ of the papers accept and $52 \%$ reject. In the semi-strong test, there is $100 \%$ acceptance of the EMH; in the strong form, $100 \%$ reject.

As for information asymmetry in Brazil, Arruda, Girão and Lucena (2015) provide a comparison of using social media and their impact on the information asymmetry level and pricing of listed companies in the Brazilian and U.S. capital markets in 2012. The authors used the Ohlson Model to verify if social media information affected stock prices and, as a proxy for information asymmetry, their volatility. With 170 Brazilian and 100 U.S. companies, the results showed that social media can affect the information asymmetry level in both markets, but only the 'unofficial' Facebook affects pricing in the Brazilian market. However, investors who do not use Facebook did not get different average returns.

Marques (2016), in the 2016 presidential impeachment context, investigates whether political news in Brazil impact the financial market - IBOVESPA returns, DI (Interbank Deposit Certificate) rates, and Special Settlement and Custody System (SELIC). The author develops a web search algorithm and measures the impact on the IBOVESPA by means of the methodology of study of events, and he also uses the generalized autoregressive conditional heteroscedasticity (GARCH) model to estimate the normal returns. He concluded that only one piece of news caused abnormal returns to the financial market, the impeachment proceedings onset. The other impacts were related to news from China and not to political issues.

\section{METHODOLOGY}

The methodology used in the quantitative part consists in the study of events whose expected normal return is based on ARMA $(p, q)$ modeling that, although simple, is sufficient for the study proposed herein. However, each impeachment phase is characterized by a time series different from another one with new information. This means that each has a different model, totaling three. The results help testing the EMH.

The study of events, according to MacKinlay (1997), is appropriate for many applications, even financial research, and it is still valid today. Some examples are related to mergers and acquisitions and announcements of macroeconomic variables, such as deficit. In most applications, the focus lies on the effect of an event on an asset class. In the case of this paper, the IBOVESPA returns were used. Its assumption is that, given an event, markets react quickly and precisely to new information.

\subsection{Procedures to Test the EMH through the Study of Events}

In this paper, the semi-strong form of the EMH is tested. The procedure, based on the study of events, must first define the dates that possibly impacted on the asset and then establish a time frame called the event window. To clarify, this time frame should involve the time of opening and closing trades on the stock exchange, for instance. Herein, the events, called $t=0$, are defined in the 2016 presidential impeachment phases or objectively on the exact date on which a certain vote occurred: Chamber, Senate I and Senate II. The phases are determined like this: 
- Chamber $-1^{\text {st }}$ impeachment voting, held by the representatives, which would refer the subject to the Federal Senate, on 4/17/2016 (however, there was no trading session on that day, so 4/18/2016 is considered as the event $t=0$ );

- Senate $I-2^{\text {nd }}$ impeachment voting, carried out by senators, which would lead to presidential leave $(t=0$ on $5 / 12 / 2016)$;

- Senate II - $3^{\text {rd }}$ impeachment voting, carried out by senators, which would lead to definitive presidential leave ( $t=0$ on $8 / 31 / 2016)$.

Assessing the impact of an event is measured by RA calculation. This is obtained by subtracting the real return from the expected return, according to equation 1 :

$$
A R_{t}=R_{t}-E\left(R_{t} \mid X_{t}\right)
$$

where $A R_{t}$ is the abnormal return, $R_{t}$ is the real return, $E\left(R_{t} \mid X_{t}\right)$ is the normal return, $X_{t}$ is the average market return constant over time and $t$ is the time in which measurement occurs.

In order to establish the event window, as observed in Figure 1, it is found that $t=0$ is the event date and from $t=T_{0}+1$ to $t=T_{1}$ is the estimation window. Then, $L_{1}=T_{1}-T_{0}$ and $L_{2}=T_{2}-T_{1}$ are the size of the estimation window and the event window, respectively. The postevent window will be the size of $L_{3}=T_{3}-T_{2}$.

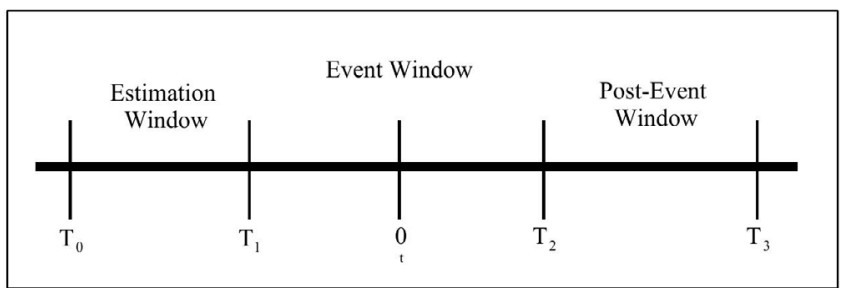

Figure 1 Event and Post-event estimation window.

Source: Adapted from MacKinlay (1997).

However, a five-day interval before the event window was inserted, because, according to Archie Craig MacKinlay, quoted by Lima et al. (2008, p. 11), it helps "preventing the estimation window from becoming too close to the event, thus avoiding possible influences in the estimation of the model chosen." The observation of IBOVESPA returns started on 9/11/2015 and this provided sufficient quantity for a safe time-series econometric model to be used. Considering that, over time, new information has been inserted, the data used for the next step after the Chamber event and the Senate I have not been eliminated. This means that, in each period, the creation of a new model is required. Besides, MacKinlay
(1997) recommends using a history of 120 observations to estimate normal returns. Observations in the event window are not counted.

The real returns are calculated continuously, as expressed by equation 2 :

$$
R_{t}=\ln \left(\frac{S_{t}}{S_{t-1}}\right)=\text { percentage return on asset }
$$

where $S_{t}$ is the asset price of date $t, S_{t-1}$ is the asset price on date $t-1$, and $\ln$ is the natural logarithm.

The expected normal returns have, as a basis for calculation, the time-series econometric model ARMA $(p, q)$. The ARMA model is given by equation 3 :

$$
y_{t}=\mathrm{a}_{0}+\sum_{\mathrm{i}=1}^{p} a_{i} y_{t-i}+\sum_{\mathrm{i}=1}^{q} \beta_{i} \varepsilon_{t-i}
$$

where $y_{t}$ in this paper, is the IBOVESPA return on date $t$; $\varepsilon_{t-i}$ is random disturbance at time $t$ and it has a distribution $\varepsilon_{t} \sim \mathrm{N}\left(0, \sigma^{2}\right), a_{0}$ is a constant, $a_{i}, i=1,2, \ldots, p$, is the parameter of the autoregressive part in the model, and $\beta_{i}, i=1,2, \ldots, q$, is the parameter of the moving average (MA) part process in the model. It is worth remembering that an $\mathrm{AR}(p)$ is a special case of an ARMA $(p, 0)$ and a MA $(q)$ may be represented by an ARMA $(0, q)$. In addition, models may or may not have all of their complete lags; when this occurs, they are called 'degenerate.' Another point that must be ratified is that each event $t=0$ of the Chamber, Senate I, and Senate II had its own estimated model, just as if based on the information available to the players so far. Thus, there are three models.

In order to obtain the normal returns, one takes the unconditional hope of equation 3. According to Enders (1995), the most important use of an ARMA model is predicting future values of the $y_{t}$ sequence. So, normal returns are obtained by equation 4 , where we take the unconditional hope of equation 3 :

$$
E\left(R_{t} / X_{t}\right)=\mathrm{E}\left(y_{t}\right)=\mathrm{a}_{0}+\sum_{\mathrm{i}=1}^{p} a_{i} E\left(y_{t-i}\right)
$$

After the abnormal returns are calculated through equations 1,2, and 4, they are summed according to the RAA technique, just as MacKinlay (1997) proposes:

$$
\mathrm{RAA}_{t}=\sum_{\mathrm{t}=1}^{T} \mathrm{RA}_{t}
$$

where $t=1,2, \ldots T$ is the AR date.

In the same direction as Camargos and Romero (2006), herein the EMH test uses the Student's $t$-test at a $5 \%$ ( $p$ value $<0.05$ ) significance level. The null hypothesis $\mathrm{H}_{0}$ is rejected when the $p$ value calculated is lower than 
the significance level $\alpha$, something which allows us to conclude that the $R A A$ is different from 0 , otherwise it would be 0 .

For the statistical test procedures, it is adopted that, in the null hypothesis $\mathrm{H}$, the event has no impact on the behavior of returns. Under $\mathrm{H}_{0}$, the sample AR distribution in the event window is:

$$
\mathrm{AR}_{t} \sim \mathrm{N}\left(0, \sigma^{2} \mathrm{AR}_{t}\right)
$$

In practical terms, $\mathrm{AR}_{t}$ is approximately the variance obtained from the ARMA $(p, q)$. Thus, the $t$ test for the $\mathrm{AR}$ at a given date are the AR on the model's standard deviation.

In turn, for inferring the RAA, the procedure is given by (7):

$$
\theta=\frac{R A A_{t}}{\operatorname{VAR}\left(R A A_{t}\right)^{0,5}}
$$

where $\theta$ is the $t$ statistics and $\operatorname{VAR}\left(R A A_{t}\right)$ is the $R A A_{t}$ variance.

The $\operatorname{VAR}\left(R A A_{t}\right)^{0.5}$ is the standard deviation for $R A A_{t}$. This is calculated by multiplying the standard deviation of residuals for their respective model with the square root of the number of days in the estimation window, including the day of the event.

To verify the ARMA $(p, q)$ model validity, a series of tests were performed: augmented Dickey-Fuller (ADF) for unit root; autocorrelation functions (FAC) and partial autocorrelation functions (FACP) to identify the models; Ljung-Box, which gives the orders for $\mathrm{p}$ and $\mathrm{q}$; the model parsimony test through the Schwarz Bayesian Criterion (SCB) - or the Schwarz Information Criterion (SIC); the Doornik-Hansen normality test; the unobserved error homoscedasticity test, the ARCH-LM.

\subsection{Statistical Hypothesis}

Then, the hypothesis tested takes the following form:

$\mathrm{H}$ : the RAA are statistically equal to 0 on the date the event is disclosed and the following day, or $\mathrm{RAA}_{\mathrm{t} 1, \mathrm{t} 2}=0$;

$\mathrm{H}$ : the RAA are not statistically equal to 0 on the date the event is disclosed and the next day, or $\mathrm{RAA}_{\mathrm{t} 1, \mathrm{t} 2}=0$.

If $\mathrm{H}$ is rejected for one of the events, it is inferred that some anomaly occurred so that the IBOVESPA did not take the semi-strong form of the EMH and, therefore, the market did not react as expected in face of the impeachment, since the index is used as a proxy for the Brazilian stock market in this paper.

\section{ANALYSIS OF RESULTS}

The analysis emerged according to what was exposed in the methodology section. The dates $t=0$ were established in 3.1 with Chamber, Senate I, and Senate II. The event windows were opened in +3 post-event observations and -3 observations before the event $t=$ 0 . The interval, however, was stipulated in -5 calendar days, rather than observations. It was assumed that it would be time enough for the estimated models not to influence the calculations. Nevertheless, not always the end of observation corresponded to 5 days before the window, due to the fact there was no trading day. When it happened, the first day before the window has been taken, as we observe in the Senate II series. Table 2 shows the intervals of the estimation dates.

Table 2

Intervals concerning the study of events

\begin{tabular}{cccccc}
\hline $\begin{array}{c}\text { Initial date of } \\
\text { observation }\end{array}$ & $\begin{array}{c}\text { Final date of } \\
\text { observation }\end{array}$ & Observations $(\mathbf{n})$ & $\begin{array}{c}\text { Event window } \\
\text { onset }\left(\boldsymbol{T}_{\boldsymbol{1}}\right)\end{array}$ & $\begin{array}{c}\text { Date of the event } \\
(\boldsymbol{t}=\mathbf{0})\end{array}$ & $\begin{array}{c}\text { Event window end } \\
\left(\boldsymbol{T}_{\mathbf{2}}\right)\end{array}$ \\
\hline $9 / 11 / 2015$ & $4 / 7 / 2016$ & 139 & $4 / 13 / 2016$ & $4 / 18 / 2016$ & $4 / 22 / 2016$ \\
\hline $9 / 11 / 2015$ & $5 / 3 / 2016$ & 156 & $5 / 9 / 2016$ & $5 / 12 / 2016$ & $5 / 17 / 2016$ \\
\hline $9 / 11 / 2015$ & $8 / 19 / 2016$ & 233 & $8 / 26 / 2016$ & $8 / 31 / 2016$ & $9 / 5 / 2016$ \\
\hline
\end{tabular}

Source: Prepared by the authors.

Figure 2 shows approximately the returns on the dates of the events $t=0$. 

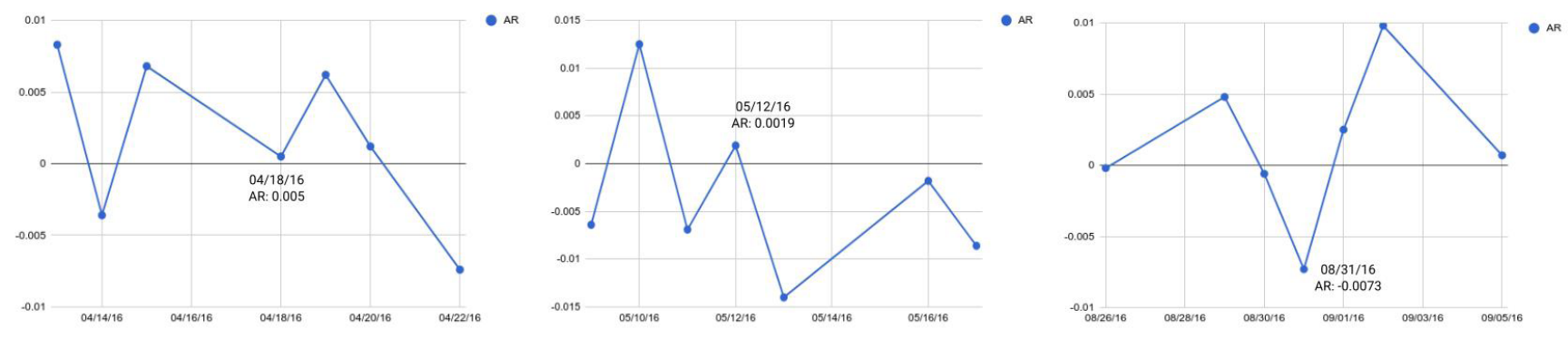

Figure 2 Approximate returns on the dates of the events. Source: Prepared by the authors.

The next step consisted in finding an appropriate timeseries model to provided the predictions needed and finding the normal returns. To do so, the series interval was specified in Table 2, with the initial date of observation and the final date of observation. Then, the time-series econometric procedures specified in section 3.1 were performed. The results are provided in Appendix 1.

Synthetically, the model found for the Chamber series was a degenerate MA (10) process with the specification observed in equation 8 :

$$
\frac{y_{t}=0.0000822+0.226491 \varepsilon_{t-10}+\varepsilon_{t}}{(0.00082)(0.0845032)}
$$

The model found for the Senate I series was a degenerate MA (10) process with the specification observed in equation 9:

$$
\frac{y_{t}=0.0027+0.204183 \varepsilon_{t-10}+\varepsilon_{t}}{(0.00076)(0.08183)}
$$

The model found for the Senate II series was a degenerate ARMA process $(10,7)$ with the specification observed in equation 10 :

$\frac{y_{t}=0.00043+0.186289 y_{t-10}-0.137968 \varepsilon_{t-7}+\varepsilon_{t}}{(0.0005)(0.0648)(0.0655)}$

where $y_{\mathrm{t}}$ is the normal return, $\varepsilon_{t}$ is random disturbance in time and $t=1,2, \ldots, T$ is the normal return date.

From then on, each time series was subject to its respective models, in order to provide the expected normal returns, through forecasting, in the event window. The AR was found, as well as the cumulative abnormal returns, and then the tests were performed by means of the $t$ statistics, as explained in section 3.1. The results are provided in appendices 2, 3, and 4 for the Chamber, Senate I, and Senate II, respectively.
When analyzing the results, it is noticed there was no statistical significance for neither AR or RAA in all estimated windows and, mainly, in all events $t=0$. This means that, statistically, we cannot reject that the hypothesis of abnormal returns and cumulative abnormal returns is equal to 0 at a $5 \%$ significance level. Through this analysis, one could evaluate that the markets were well-informed regarding the events, i.e. by the EMH in the semi-strong form, the markets reacted as expected, therefore, the EMH would be valid for the domestic market.

By means of economic analysis, this might be expected, since, at the time of the events, there were great expectations that the impeachment would take place, indeed. The press, demonstrations by population portions (although other portions were also demonstrating against it), and declarations by authorities from the three powers (Judiciary, Executive, and Legislative) have created a scenario unfavorable to the presidency. Thus, the markets adjusted continuously and immediately to the new information provided. As a consequence, there was not a big surprise or information asymmetry, for instance, to generate abnormal returns or accumulate significant abnormal returns.

Due to this economic issue, on the other hand, it is debatable to arrive at a generic analysis that the Brazilian stock market was efficient, since there was no AR. One can make analogy to a total-point football competition, where the champion is already known with many rounds in advance, but the winning team of the event must comply with the table. So, any kind of information would be irrelevant.

The only possibility of changing the scenario might be some extraordinary factor, such as a player irregularly scheduled or, in the impeachment case per se, a radical change in the voting direction, causing an unusual return. At this point, new and immediate information would be extremely relevant to identify market efficiency. There 
would be a change in the 'rules of the game', as discussed in section 2.1, hence economic players might set out for an information-seeking race and they could adapt rationally to new expectations. Perhaps, there would be a good opportunity for an effective EMH test. However, that was not the reality. There was an information flood and the scenario might be rather identified with the football competition example.

\section{FINAL REMARKS}

This article verified, through the EMH, in the semistrong form, whether the stock market reacted as expected in face of the 2016 presidential impeachment. As a proxy for the market, the IBOVESPA returns were used. Three major events in the process were evaluated, with their respective periods, named as Chamber, Senate I, and Senate II. According to the time series analyzed in each period, it was verified that the best models to find the abnormal returns, based on an $\operatorname{ARMA}(p, q)$, were MA (10), MA (10) and ARMA (10, 7), all degenerate, respectively. These provided the expected normal returns for the study of events, a technique adopted to capture semi-strong efficiency.

After the calculation of abnormal returns and cumulative abnormal returns, no significant statistics has beed found, at the $5 \%$ level, in all the estimated windows and in all their events $t=0$. Statistically, one cannot reject the hypothesis that the abnormal returns and the accumulated abnormal returns are equal to 0 . Then, it was found that the markets were well-informed in relation to the events, i.e. by the $\mathrm{EMH}$, in the semistrong form, the markets reacted as expected, providing no AR and suggesting efficiency.

According to the results, it might be intuitive to believe that the markets seemingly adjusted on a continuous and immediate basis to new information provided. There would be no information asymmetry, or anything of the sort, to generate abnormal returns or accumulate significant abnormal returns.

What has been found herein, in this regard, is not dissonant with the papers exhibited in the literature review. The impeachment is not an election, but by making a certain abstraction, it can work as such if it is considered as a sort of election in which the authority will remain in office or not. Thus, the results are consistent with the fact there was little uncertainty about the confirmation of impeachment, which characterized rather solid expectations providing returns closer to normal, i.e. the results are in line with the findings provided by Gemmil (1992) and Gwilym and Buckle (1994). Although we expected the result in advance, it is believed that there would be hardly any abnormal returns, as suggested by Aggarwal and Smith (2015), and, likewise, little anomaly was found in the sense of Altin (2015).

In relation to the national literature, either by Camargos and Barbosa (2006) or Medeiros and Barbosa (2007), contrary to the results of their research, in this specific situation, in face of the analysis discussed herein, it is not possible to judge there has been information asymmetry or lack of efficiency in this condition. Taking information as a subject, although with a different approach, the study did not capture there was information weakness, in this case, and in the direction taken by Arruda et al. (2015), where the average investor would get normal returns unrelated to the votes. Regarding the normality of return, the finding was approximately the same as that reported by Marques (2016), who also addressed the theme, i.e. there was not. The author, however, based on news, found $\mathrm{AR}$ in the impeachment disclosure, an event that has not been covered herein.

It is worth emphasizing that the quantitative analysis was carried out just as stated in the methodology section, according to the authors' assumptions and recommendations. The results, specifically in this case, eventually provided efficiency. Nevertheless, this does not mean that the market has actually reacted in an efficient manner. Although it showed statistical characteristics for this, myopia may have occurred. It is explained: how it is feasible that economic players could have been expected the impeachment to be confirmed, perhaps the indifference to the voting results in a rather heated manner, as well as their expectations, were only a confirmation of what was obvious. No information other than changing the 'rules of the game' could provide some AR.

Other issues that may affect the results consist in the limitations arising from the window chosen, a series of factors, or issues arising from the methodology itself, as addressed by Altin (2015), as they may not capture market efficiency in its fullness. The studies addressed by Forti et al. (2009) clearly demonstrate antagonistic directions in the Brazilian market. This means that anomalies depend on the market according to the contexts, most likely to this situation, a point conveniently highlighted by Altin (2015). The study is not definitive and further research on this theme is suggested. 


\section{REFERENCES}

Acemoglu, D. (2005). Politics and economics in weak and strong states. Journal of Monetary Economics, 52(7), 1199-1226.

Aggarwal, A. K., \& Smith, F. (2015). Investing in presidential elections: using poll data to earn abnormal returns. Journal of Business and Economics, 6(4), 625-633.

Altin, H. (2015). Efficient market hypothesis, abnormal return and election periods. European Scientific Journal 11(34), 169-178.

Arruda, M. P., Girão, L. F. de A., \& Lucena, W. G. L. (2015). Assimetria informacional e o preço das ações: análise da utilização das redes sociais nos mercados de capitais brasileiro e norte-americano. Revista Contabilidade \& Finanças 26(69), 317-330.

Brasil. (2016, August). Resolução do Senado Federal n. 35, de 31 de agosto de 2016. Dispõe sobre sanções no Processo de Impeachment contra a Presidente da República, Dilma Vana Rousseff, e dá outras providências. Retrieved from http://pesquisa.in.gov.br/imprensa/jsp/visualiza/index. jsp? jornal $=1000 \&$ pagina $=1 \&$ data $=31 / 08 / 2016$

Camargos, M. A., \& Barbosa, F. V. (2006). Eficiência informacional do mercado de capitais brasileiro pós-Plano Real: um estudo de eventos dos anúncios de fusões e aquisições. Revista de Administração, 41(1), 43-58.

Camargos, M. A., \& Romero, J. A. R. (2006). Análise empírica da reação do mercado de capitais brasileiro a eventos corporativos: teste conjunto da hipótese de eficiência do mercado. Revista de Gestão USP, 13(3), 57-74.

Elder, A. (2002). Come into my trading room: a complete guide to trading. New York: John Wiley and Sons.

Enders, W. (1995). Applied econometric time series. New York: John Wiley and Sons.

Fama, E. F. (1970). Efficient capital markets: a review of theory and empirical work. The Journal of Finance, 25(2), 383-417.
Fama, E. F. (1991). Efficient capital markets: II. The Journal of Finance, 46(5), 1575-1617.

Forti, C. A., Peixoto, F. M., \& Santiago, W. P. (2009). Hipótese da eficiência de mercado: um estudo exploratório no mercado de capitais brasileiro. Gestão \& Regionalidade, 25(75), 45-56.

Gemmil, G. (1992). Political risk and market efficiency: tests based in British stock and options markets in the 1987 election. Journal of Banking and Finance, 16(1), 211-231.

Gwilym, O. A., \& Buckle, M. (1994). The efficiency of stock and options markets: tests based on 1992 UK election opinion polls. Applied Financial Economics, 4(5), 345-354.

Lima, G. A. S. F., Yamamoto, M. M., Lima, I. S., \& Malacrida, M. J. C. (2008). Um estudo da eficiência informacional do mercado acionário brasileiro. Revista de Informação Contábil, 2(1), 1-18.

Mackinlay, A. C. (1997). Event studies in economics and finance. Journal of Economic Literature, 35(1), 13-39.

Marques, T. B. (2016). Do the political news impact financial markets? Evidences from Brazil (monograph). Porto Alegre: Universidade Federal do Rio Grande do Sul. Retrieved from http://www.lume.ufrgs.br/handle/10183/167236

Medeiros, O. R., \& Barbosa, G. C. (2007). Teste empírico da eficiência do mercado brasileiro na ocorrência de eventos favoráveis e desfavoráveis. Revista de Negócios, 12(4), 44-54.

North, D. C. (1990). Institutions, institutional change and economic performance. Cambridge: Cambridge University Press.

Sallum Jr., B., \& Casarões, G. S. P. (2011). O impeachment do presidente Collor: a literatura e o processo. Lua Nova, 82, 163-200.

Van der Brug, W., Van der Eijk, C., \& Franklin, M. (2007). The economy and the vote: economic conditions and elections in fifteen countries. London, United Kingdom: Cambridge University Press. 
Appendix 1

Analysis and testing procedures to identify the time series model to obtain the expected returns

\begin{tabular}{|c|c|c|c|c|}
\hline & & & Calculated statistics & \\
\hline Procedure & Null hypothesis & Chamber & Senate I & Senate II \\
\hline $\begin{array}{l}\text { Dickey Fuller Test } \\
\text { (Akaike information } \\
\text { criterion) }\end{array}$ & $\begin{array}{l}\text { Existence of unit root } \\
\quad \text { (constant test) }\end{array}$ & $\begin{array}{c}\text { tau_c(1) } \\
-10.5807 \\
p \text { value } \\
5.071 \times 10^{-16}\end{array}$ & $\begin{array}{c}\text { tau_c(1) } \\
-11.1417 \\
p \text { value } \\
1.69 \times 10^{-17}\end{array}$ & $\begin{array}{c}\text { tau_c }(1) \\
-10.4238 \\
p \text { value } \\
8.966 \times 10^{-16}\end{array}$ \\
\hline $\begin{array}{l}\text { Autocorrelation and partial } \\
\text { autocorrelation functions }\end{array}$ & Lagged truncation & $\begin{array}{c}\text { Def. } 10 \\
\text { Q-stat } \\
13.2603 \\
p \text { value } \\
0.209\end{array}$ & $\begin{array}{c}\text { Def. } 10 \\
\text { Q-stat } \\
14.7582 \\
p \text { value } \\
0.141\end{array}$ & $\begin{array}{c}\text { Def. 7. } 10 \\
\text { Q-stat } \\
\text { (7) } 6.6023 \\
(10) 15.9653 \\
p \text { value } \\
\text { (7)0.471 } \\
(10) 0.101\end{array}$ \\
\hline Schwarz's Bayesian criterion & Choice of best fit model & $\begin{array}{c}\text { Degenerate MA(10) } \\
-932.0679\end{array}$ & $\begin{array}{c}\text { Degenerate } \mathrm{MA}(10) \\
-1046.216\end{array}$ & $\begin{array}{c}\text { Degenerate ARMA(10.7) } \\
-1610.341\end{array}$ \\
\hline $\begin{array}{c}\text { Autocorrelation test } \\
\text { Ljung-Box }\end{array}$ & All autocorrelation equals 0 & $\begin{array}{c}\mathrm{Q}^{\prime} \\
2.5016 \\
p \text { value } \\
\mathrm{P}\left(\chi^{2}(4)>2.11315\right) \\
=0.7150\end{array}$ & $\begin{array}{c}\mathrm{Q}^{\prime} \\
2.86362 \\
p \text { value } \\
\mathrm{P}\left(\chi^{2}(4)>2.86362\right) \\
=0.580\end{array}$ & $\begin{array}{c}\mathrm{Q}^{\prime} \\
1.37963 \\
p \text { value } \\
\mathrm{P}\left(\chi^{2}(3)>1.37963\right) \\
=0.7103\end{array}$ \\
\hline Residual normality test & $\begin{array}{c}\text { Normal distribution } \\
\text { hypothesis }\end{array}$ & $\begin{array}{c}\chi^{2}(2)=4.160 p \text { value } \\
0.12496\end{array}$ & $\begin{array}{c}\chi^{2}(2)=3.667 p \text { value } \\
0.15982\end{array}$ & $\begin{array}{c}\chi^{2}(2)=4.887 p \text { value } \\
0.08686\end{array}$ \\
\hline ARCH effect test & No ARCH effect is present & $\begin{array}{l}\left.P \chi^{2}(5)>6.90515\right) \\
\quad=0.22779\end{array}$ & $\begin{array}{l}\left.P \chi^{2}(5)>8.23043\right) \\
\quad=0.143985\end{array}$ & $\begin{array}{l}\left.\mathrm{P} \chi^{2}(5)>8.74545\right) \\
\quad=0.119658\end{array}$ \\
\hline Model's standard error & - & 0.008012 & 0.008050 & 0.007281 \\
\hline Residual standard deviation & - & 0.0080514 & 0.0080833 & 0.007266 \\
\hline
\end{tabular}

ARCH = autoregressive conditional heteroscedasticity.

Source: Prepared by the authors.

\section{Appendix 2}

Chamber event results for the efficient-market hypothesis test

\begin{tabular}{ccccc}
\hline Date & AR & Test $\boldsymbol{R}$ & RAA & 0.3891 \\
\hline $4 / 13 / 2016$ & 0.0083 & 1.0345 & 0.0083 & 0.0047 \\
\hline $4 / 14 / 2016$ & -0.0036 & -0.4498 & 0.0115 & 0.5410 \\
\hline $4 / 15 / 2016$ & 0.0068 & 0.8536 & 0.0120 & 0.5636 \\
\hline $4 / 18 / 2016$ & 0.0005 & 0.0601 & 0.0182 & 0.8550 \\
\hline $4 / 19 / 2016$ & 0.0062 & 0.7748 & 0.0194 & 0.9095 \\
\hline $4 / 20 / 2016$ & 0.0012 & 0.1449 & 0.0120 & 0.5640 \\
\hline $4 / 22 / 2016$ & -0.0074 & -0.9186 & & \\
\hline
\end{tabular}

Note: The lines in italics correspond to the event $t=0$.

$A R=$ abnormal return; $R A A=$ cumulative abnormal return.

Source: Prepared by the authors. 
Appendix 3

Senate I event results for the efficient-market hypothesis test

\begin{tabular}{ccccc}
\hline Date & AR & Test $\boldsymbol{R}$ & RAA & Test $\boldsymbol{t}$ \\
\hline $5 / 9 / 2016$ & -0.0064 & -0.7914 & -0.0064 & -0.2979 \\
\hline $5 / 10 / 2016$ & 0.0125 & 1.5559 & 0.0062 & 0.2878 \\
\hline $5 / 11 / 2016$ & -0.0069 & -0.8522 & -0.0007 & -0.0330 \\
\hline $5 / 12 / 2016$ & 0.0019 & 0.2339 & 0.0012 & 0.0550 \\
\hline $5 / 13 / 2016$ & -0.0140 & -1.7438 & -0.0129 & -0.6013 \\
\hline $5 / 16 / 2016$ & -0.0018 & -0.2239 & -0.0147 & -0.6856 \\
\hline $5 / 17 / 2016$ & -0.0086 & -1.0707 & -0.0233 & -1.0886 \\
\hline
\end{tabular}

Note: The lines in italics correspond to the event $t=0$.

$A R=$ abnormal return; $R A A=$ cumulative abnormal return.

Source: Prepared by the authors.

\section{Appendix 4}

Senate II event results for the efficient-market hypothesis test

\begin{tabular}{ccccc}
\hline Date & AR & Test $\boldsymbol{t}$ & RAA & Test $\boldsymbol{t}$ \\
\hline $8 / 26 / 2016$ & -0.0002 & -0.0334 & -0.0002 & -0.0126 \\
\hline $8 / 29 / 2016$ & 0.0048 & 0.6564 & 0.0045 & 0.2360 \\
\hline $8 / 30 / 2016$ & -0.0006 & -0.0767 & 0.0040 & 0.2069 \\
\hline $8 / 31 / 2016$ & -0.0073 & -1.0046 & -0.0033 & -0.1736 \\
\hline $9 / 1 / 2016$ & 0.0025 & 0.3390 & -0.0009 & -0.0452 \\
\hline $9 / 2 / 2016$ & 0.0098 & 1.3396 & 0.0089 & 0.4622 \\
\hline $9 / 5 / 2016$ & 0.0007 & 0.0937 & 0.0096 & 0.4977 \\
\hline
\end{tabular}

Note: The lines in italics correspond to the event $t=0$.

$A R=$ abnormal return; $R A A=$ cumulative abnormal return.

Source: Prepared by the authors. 